RESENHA

\title{
A pedagogia, a democracia, a escola
}

Caroline Jaques Cubas'

Masschelein, J.; Simons, M. A pedagogia, a democracia, a escola. Belo Horizonte: Autêntica, 2014.

Debates em torno da educação estão particularmente na ordem do dia. Compõem discussões de um tempo presente que habitaram, igualmente, presentes passados. A escola, enquanto instituição, e tudo o que é possibilitado nela/por ela, passou por diferentes processos de apropriação, sendo, muitas vezes, instrumentalizada para finalidades e projetos políticos de diferentes matizes, em diferentes tempos. Masschelein e Simons (2014), ao proporem a possibilidade de um olhar atento à pedagogia, à democracia e à escola falam, portanto, de um tema absolutamente presente. Preocupam-se com desafios da educação no presente, apartando, porém, a escola de tudo o que se atribuiu a ela.

Os três substantivos que dão nome à obra entrecruzam-se ao longo dos diferentes capítulos. Os textos que compõem o volume, ainda que escritos em momentos diferentes, tratam de pensar a educação e de conceber uma sorte de "filosofia da educação" não apenas como campo ou exercício intelectivo, mas como a formação mesma de um ethos. Para tanto, lançam-se a uma série de exercícios críticos a respeito da educação, partindo, porém, de uma concepção de crítica pautada por aquilo que chamam de "uma tradição ascética" (Masschelein e Simons, 2014, p. 11), a qual diz respeito menos a um exercício analítico ou à elaboração de um julgamento valorativo do que à possibilidade de uma experiência e/ou exposição às questões sobre as quais se demoram.

Consistentemente pautado por autores como Hannah Arendt (2014) e Jacques Rancière (2015), A pedagogia, a democracia, a escola constitui-se como provocativo convite ao pensamento. Os três substantivos denominam não apenas a obra, mas as partes que a compõem. Assim, além de entrecruzarem-se, possibilitam uma reflexão mais pormenorizada de temas já trabalhados pelos autores no igualmente instigante Em defesa da Escola (Masschelein e Simons, 2013), como a problematização da noção de público e a presunção da igualdade como ponto de partida da prática educativa (e não como objetivo a ser atingido). 
A primeira parte, a pedagogia, apresenta, ao longo de três artigos, reflexões a respeito do ato pedagógico. Para tanto, inicia-se justamente com proposições sobre um dos sujeitos do pedagógico, a saber, o aluno. Por meio de um cuidado bastante evidente com as palavras (cuidado esse perceptível durante todo o volume), tais proposições são fundamentadas na distinção entre a pedagogia e o pedagógico, bem como entre aluno e infância. A empreitada objetiva particularmente libertar a figura do aluno de tudo aquilo que a ele se integra quando é compreendido como sujeito de uma pedagogia que busca conduzir os alunos "ao saber, ao conhecimento $e$ à competência" (Masschelein e Simons, 2014, p. 34, grifos meus). A infância, nesse sentido, aparece como alternativa. Não é pensada como um estado ou limitada por uma idade, mas apresentada, a partir de Rancière, como potência e exposição. Tal percepção, segundo os autores, torna possível a posição do professor ou professora em um espaço pedagógico que nunca é preexistente e que possibilita o aprendizado como exercício dessa potência, característica da infância. O professor é aquele responsável por manter essa condição de infância, cujas características principais são justamente são justamente a potência e as noções igualmente rancierianas de vontade e igualdade. Rompe-se, dessa forma, a ideia de uma relação pedagógica hierárquica e apresenta-se a noção de uma pedagogia pobre, desenvolvida no artigo seguinte por intermédio da sugestiva relação entre a caminhada e o exercício da leitura e escrita como forma de pensar o ato de exposição, também característico dessa concepção particular de infância. O caminhar aparece como elogio ao exercício, à atenção e à presença no ato educativo. Essa pedagogia pobre, desprovida de intenções excedentes, propõe restituir o lugar do tempo e do espaço como locus de atenção que, quando apartados de demandas produtivistas, podem efetivamente possibilitar experiência. A educação (no ensino e na pesquisa educativa) está, portanto, relacionada à possibilidade de experiência.

A segunda parte do livro é dedicada à ideia de democracia. As referências a Rancière fazem-se explícitas inclusive no título de dois dos três textos que compõem essa seção. Os temas da igualdade e da dimensão pública como categoria quase que inerente da compreensão de educação apresentada pelos autores merecem particular atenção. Para tanto, retomam $O$ mestre ignorante (Rancière, 2015) e reapresentam a noção de igualdade como ponto de partida. Nesse sentido, a educação não teria como objetivo a preparação para o exercício político, mas traz em seu fundamento a ideia de que todos são capazes de (aprender, pensar). A educação diz respeito à potencialidade e, dessa forma, fundamenta-se em um princípio de igualdade. Pensando a democracia como o poder dos que não têm poder (Masschelein e Simons, 2014), ao partir da igualdade cria-se a possibilidade de que momentos democráticos possam emergir no espaço escolar. Obviamente, tal percepção não é simples e abre espaço para uma série de interpelações, especialmente no que concerne ao lugar das diferenças nesse mesmo espaço. Os autores não se detêm nesse debate. Não por desconsiderarem as diferenças que obviamente existem e são cotidianamente constatadas, mas por reivindicarem para a escola a possibilidade de suspendê-las (mesmo que por um breve momento) em nome daquilo que é considerado comum a todos e todas. É ao promover esses momentos de igualdade que a escola pode, efetivamente, tornar-se um espaço público. Eis então a necessi- 
dade de refletir sobre as categorias espaço e tempo em relação à escola. Para tanto, revisitam a concepção grega de skholé, que, em princípio, significava tempo livre. A escola enquanto espaço público deve oportunizar uma separação dos espaços e uma liberação do tempo. Compreendida como lugar de estudo e exercício, deve ser apartada das demandas e normas que vigoram na vida produtiva. Apropriando-se da terminologia de Agamben, os autores sugerem a ideia de profanação como prerrogativa de tudo que compõe o escolar. Profanação no sentido de destituir as coisas, o tempo e o espaço de seus usos comuns (Agamben, 2005). É apenas a partir dela que se pode pensar a escola como instituição pública.

A escola, em si, é o objeto da terceira parte do livro. É nela que os autores dedicam atenção às suas formas e materialidades. A ideia de skholé, de tempo livre e de separação dos espaços, ganha centralidade na tentativa de definição dos elementos que caracterizam o escolar. às categorias já delineadas soma-se a noção de abertura do mundo, de clara inspiração arendtiana. A escola, ao oportunizar tempos e espaços destituídos das funções que comumente possuem na chamada vida produtiva, possibilita ao jovem uma apresentação do mundo. Uma apresentação responsável, na medida em que não deve aprisionar sentidos e funções, e sim possibilitar a renovação daquilo que é conhecido e apresentado. Tal apresentação cabe objetivamente à figura do professor e da professora. Nesse atento exercício de pensamento sobre o que constitui o escolar, os autores materializam a proposição por meio da apresentação e descrição detalhada do modelo arquitetônico que, em si, também é dado ao uso comum. Nesse ponto, chega-se à assertiva de que "ser pública é a essência da escola" (Masschelein e Simons, 2014, p. 191, grifo do original).

O livro é encerrado pela profícua correspondência entre Jan Masschelein e Walter Kohan - que também assina o prefácio da edição - acerca das possibilidades e dos desafios de se pensar a filosofia como educação e a educação como filosofia. Por meio de referências diversas, que vão da filosofia clássica ao pós-estruturalismo, não encerram a questão, mas desenvolvem inúmeras possibilidades de reflexão levando-nos, por intermédio de diferentes possibilidades de percurso, a (re) pensar o que fundamenta, em termos epistemológicos e experienciais, o pensar-se como professor(a).

Se Em defesa da escola Jan Masschelein e Maarten Simons já haviam assumido o ousado exercício de sugerir a existência de elementos que definem o escolar de forma praticamente intemporal, $A$ pedagogia, a democracia, a escola retoma e amplia o exercício. Ousado, arrisca ser acusado de elogio ao modelo tradicional ou conservador de escola, em função dessa presumida intemporalidade. Cabe lembrar, porém, que tal modelo buscava preparar os alunos e as alunas para o ingresso adequado em uma sociedade específica, enquanto aqui professa-se justamente a necessidade de uma escola que garanta a possibilidade da renovação. Ampliam o exercício ao inserirem elementos outrora trabalhados (como as noções de suspensão, profanação e tempo livre) em uma ideia de democracia constituída a partir das noções de igualdade e de público, as quais se tornam, por sua vez, indissociáveis e indispensáveis para a ideia de escola aqui desenhada. O livro, tal qual Sócrates nas palavras de Kohan, provoca em quem o percorre a impossibilidade de passividade. Ao final do volume 
os substantivos são (re)formados e instituem-se como possibilidades apenas por meio de ação: A pedagogia, a democracia, a escola apresenta, assim, um provocativo e contundente convite a fazer pedagogia, fazer democracia, fazer escola.

\section{REFERÊNCIAS}

Agamben, G. Profanações. São Paulo: Boitempo, 2007.

Arendt, H. Entre o passado e o futuro. São Paulo: Perspectiva, 2014.

Masschelein,J.; Simons, M. Em defesa da escola: uma questão pública. Belo Horizonte: Autêntica, 2013.

RANCIÈre, J. O mestre ignorante. Belo horizonte: Autêntica, 2015.

\section{SOBRE A AUTORA}

Caroline Jaques Cubas é doutora em história pela Universidade Federal de Santa Catarina (UFSC). Professora da Universidade do Estado de Santa Catarina (UDESC).

E-mail: caroljcubas@gmail.com

Recebida em 10 de novembro de 2016

Aprovada em 23 de março de 2017 